\title{
Vroča točka v mestu: povezava ekosistemskih storitev in biotske pestrosti mestnih zelenih površin
}

\author{
Špela ŽELEZNIKAR ${ }^{1}$, Klemen ELER ${ }^{2}$, Marina PINTAR ${ }^{3}$
}

Received September 23, 2016; accepted January 05, 2017.

Delo je prispelo 23. septembra 2016, sprejeto 05. januarja 2017.

\section{IZVLEČEK}

Zelene površine $\mathrm{v}$ mestih ter ekosistemske storitve (ES), ki se na teh površinah oblikujejo, nudijo prebivalcem različne posredne in neposredne koristi. Nabor teh storitev je odvisen tudi od biotske pestrosti (BP) določene zelene površine. Namen raziskave je bil ugotoviti povezavo med BP in naborom ES v določeni kategoriji zelenih površin. V izbranih devetih kategorijah v Mestni občini Ljubljana, smo opravili 108 vegetacijskih popisov $\mathrm{v}$ jesenskem in spomladanskem času. Vsaki kategoriji smo nato ocenili nabor zaznanih ES na terenu ter jih primerjali $\mathrm{z}$ zaznanimi ES takih površin iz literature. V rezultatih je tako po številu vrst kot po številu ES izstopala kategorija gozdov. Ostale kategorije so bile v sestavi vegetacije med seboj podobne, največja podobnost je bila $\mathrm{v}$ kategorijah s traviščno vegetacijo. Ugotovljena je bila pozitivna zveza med številom rastlinskih vrst in številom zaznanih ES v posamezni kategoriji zelenih površin.

Ključne besede: urbani ekosistemi; zelena infrastruktura; rastlinska vrstna pestrost; kategorije zelenih površin; Ljubljana

\section{ABSTRACT \\ CITY HOTSPOT: LINKAGES BETWEEN ECOSYSTEM SERVICES AND BIODIVERSITY OF URBAN GREEN AREAS}

Green areas in cities and their ecosystem services (ES) offer residents various benefits. The range of services depends on biodiversity of a green space. The aim was to determine the relationship between biodiversity in different categories of green areas in the city and the ecosystem services, which appear in it. We made 108 relevés in the autumn and spring time, within nine categories of green areas in the Municipality of Ljubljana. In each category the range of ES was assessed based on field analysis and compared with literature assessed ecosystem services. Results showed that the category of forests differ from others. Other categories were similar to each other, in particular grassland categories. Also, a positive relationship linkage was found - more plant species mean more assessed ecosystem services in a specific green infrastructure category.

Key words: biodiversity; ecosystem services; green infrastructure; green spaces; green infrastructure categories; Ljubljana

\section{UVOD}

Povezavo urbanih okolij ter narave $\mathrm{v}$ mestu najlažje prepoznamo in opazujemo $\mathrm{v}$ različnih oblikah mestnih zelenih površin. Že leta 1996 je Evropska komisija objavila, da so zelene površine $\mathrm{v}$ mestih enako pomembne kot ostala mestna infrastruktura (European Commission, 1996). Zelene površine, tudi zelena infrastruktura, so lahko gozdovi, parki, mestni vrtički, športna igrišča, pokopališča, vrtovi in dvorišča (GómezBaggethun and Barton, 2012). V mestu predstavljajo javno ali zasebno površino, prekrito $\mathrm{z}$ vegetacijo, ki je posredno ali neposredno povezana s svojimi uporabniki (Baycan-Levent in sod., 2009). Te površine vplivajo na kakovost življenja v

1 Univerza v Ljubljani, Biotehniška fakulteta, Oddelek za agronomijo, Jamnikarjeva 101, SI - 1111 Ljubljana, Slovenija, spela.zeleznikar@bf.uni-lj.si

2 Doc. dr. Univerza v Ljubljani, Biotehniška fakulteta, Oddelek za agronomijo, Jamnikarjeva 101, SI - 1111 Ljubljana, Slovenija

3 Prof. dr. Univerza v Ljubljani, Biotehniška fakulteta, Oddelek za agronomijo, Jamnikarjeva 101, SI - 1111 Ljubljana, Slovenija

Članek je nastal na osnovi podatkov magistrske naloge Špele Železnikar. Mentor: doc. dr. Klemen Eler, somentorica: prof. dr. Marina Pintar

This article is based on the Master Thesis of Špela Železnikar. Supervisor: Assist. Prof. Ph. D. Klemen Eler, co-supervisor: Prof. Ph. D. Marina Pintar 
mestu, na klimo v mestu, zagotavljajo svež zrak ter zmanjšujejo vplive onesnaževanja. Prav tako omogočajo medsebojno interakcijo prebivalcev, $\mathrm{v}$ njih lahko pridobivamo različne surovine ter delujejo kot vidna in zvočna pregrada. Te koristi za človeka imenujemo ekosistemske storitve (ES), ki se $\mathrm{v}$ urbanih območjih $\mathrm{v}$ različnih kategorijah zelenih površin različno izražajo (Cilliers in sod., 2011). Koncept ES, je bil oblikovan v poročilu »Millennium Ecosystem Assessment« (2005), ki poudarja, da mora biti splošna klasifikacija ES prilagojena vrstam ekosistemov, v katerih opredeljujemo storitve.

Z naraščanjem priljubljenosti koncepta ES se vse bolj izpostavlja vprašanje, kako so ES in BP povezani med seboj ter ali je BP že sama po sebi ekosistemska storitev (Jax in Heink, 2015). Še danes, čeprav obstajajo številne raziskave, ki nakazujejo pozitiven odnos med BP in naborom ES (Egoh in sod., 2009, Cardinale, 2011, Isbell in sod., 2011, Mace in sod., 2012, Harrison in sod., 2014), ni veliko jasnega o njuni povezavi ter mehanizmu te povezave (Loreau in sod., 2001, Harrison in sod., 2014). Zanimanje za ES mestnih ekosistemov (Bolund in Hunhammar, 1999) se pojavi kmalu po začetkih vrednotenja (glej Costanza in sod., 1997). Raziskovalci in načrtovalci mest iz različnih disciplin poudarjajo vlogo mestne BP pri zagotavljanju ES za povečanje blaginje ljudi v hitro urbanizirajočem se svetu (Botzat in sod., 2016).

$\mathrm{Na}$ zelene površine ter njihovo BP v mestu vpliva tudi urbanizacija. Tako nastajajo spremenjeni ekosistemi, oziroma nove, unikatne oblike mestnih zelenih površin (McKinney, 2006; Schneider in sod., 2012; Bolund in Hunhammar, 1999). Díaz in sod. (2005) ter Balvanera in sod. (2006) navajajo, da je dokazan pozitiven vpliv večje BP na količino in kakovost ES. Te so pogosto odvisne od funkcionalnih lastnostih osnovnih rastlinskih združb, ki te ekosisteme sestavljajo (De Bello in sod., 2010). Med njimi je vegetacija dober pokazatelj BP, saj oblikuje strukturo organizmov na višjih trofičnih ravneh (Smith in sod., 2006). Vegetacija mestnih zelenih površin deluje predvsem kot bio-indikator ekološke funkcije za mesto (Borysiaket in sod., 2014).

Zelene površine $\mathrm{v}$ mestih ter ES, ki se na teh površinah oblikujejo, nudijo prebivalcem različne posredne in neposredne koristi. Namen naše raziskave je bil ugotoviti povezavo med BP in naborom ES $\mathrm{v}$ različnih kategorijah zelenih površin. $Z$ raziskavo preverjamo hipotezo, da se $\mathrm{Z}$ večanjem števila rastlinskih vrst $\mathrm{v}$ posamezni kategoriji zelenih površin povečuje nabor zaznanih ES.

\section{MATERIALI IN METODE}

\subsection{Območja raziskave}

Na območju Mestne občine Ljubljana smo izbrali devet kategorij zelenih površin, ki smo jih razdelili na štiri lokacije popisov (Preglednica 1). Te kategorije so bile kategorizirane v projektu Green Surge, (7. okvirni program EU za raziskave, FP7ENV.2013.6.2-5-603567) (GS, 2016). 
Preglednica 1: Izbrane kategorije zelenih površin, razdeljene po območjih popisov v Mestni občini Ljubljana

Table 2: Areas of relevés within urban green infrastructure categories in Municipality of Ljubljana

\begin{tabular}{ll}
\hline Kategorije zelenih površin & Območja popisov \\
\hline Gozd & Rožnik, Golovec, Pržan, Tomačevski prod \\
\hline Park & Tivoli, Zvezda, Arturo Toscanini, Navje \\
\hline Drevoredi & Cesta v Rožno dolino, Vojkova cesta ob ARSO, Celovška cesta, Žale \\
\hline Igrišča & Mostec, Golf Ljubljana, Rugby Gunclje, Kodeljevo \\
\hline Zelene površine ob blokih & $\begin{array}{l}\text { Šišenska cesta (Šiška), Glinškova ploščad, Jamova cesta, Nusdorferjeva } \\
\text { ulica }\end{array}$ \\
\hline Vrtovi ob hišah & $\begin{array}{l}\text { Vič (Idrijska ulica), Šentvid (Kozlarjeva pot), Bežigrad (Dunajska cesta), } \\
\text { Štepanjsko naselje (Ob potoku) }\end{array}$ \\
\hline Vrtički & Livada, Litostroj, draveljski vrtovi, krakovski vrtovi \\
\hline Njive & Kleče, Polje, Barje, Podutik \\
\hline Ruderalna območja & $\begin{array}{l}\text { trgovska cona Rudnik, stadion Stožice, gramoznica Stanežiče, parkirišče } \\
\text { za železniško postajo Ljubljana }\end{array}$ \\
\hline
\end{tabular}

\subsection{Popisi rastlinske pestrosti}

Na vsaki lokaciji smo izvedli vegetacijski popis na naključno razporejenih treh kvadratnih ploskvah $\mathrm{v}$ velikosti $9 \mathrm{~m}^{2}$. Skupaj smo tako opravili 216 vegetacijskih popisov, $108\left(\begin{array}{lllllll}9 & \mathrm{x} & 4 & \mathrm{x} & 3\end{array}\right) \mathrm{v}$ pomladnem ter $108 \mathrm{v}$ jesenskem času $(9 \times 4 \times 3)$. Posamezne popisne ploskve so bile iste za jesenske in pomladanske popise.

Vegetacijski popis smo izvedli po BraunBlanquetovi metodi (povzeto po Dierschke, 1994), $\mathrm{s}$ pomočjo katere smo ocenjevali zastopanost posameznih vrst višjih rastlin po kombinirani lestvici, ki združuje številčnost in pokrovnost posamezne vrste. Vzorčili smo samo pojavljanje spontane vegetacije in ne sajenih rastlin. Popisi so potekali v jesenskem (med 30. 8. 2013 in 18. 10. 2013) in spomladanskem času (med 3. 5. 2014 in 26. 6. 2014). Poleg popisov na $9 \mathrm{~m}^{2}$ ploskvah smo popisali tudi rastlinske vrste (spontano pojavljanje) v okolici ploskev. Pri popisih v gozdovih smo upoštevali vertikalno strukturiranost združbe $\mathrm{z}$ ugotavljanjem zastopanosti vrst po treh plasteh: drevesni (lesnate vrste nad $5 \mathrm{~m}$ višine), grmovni (lesnate vrste od 0,5 do $5 \mathrm{~m}$ višine) in zeliščni. $\mathrm{Za}$ vsak posamezni popis smo ugotovili število rastlinskih vrst na popis in izračunali vrednost Shannon-Wiennerjevega indeksa pestrosti. Ocene po Braun-Blanquetovi kombinirani lestvici smo za izračun indeksa pretvorili v deleže $\mathrm{z}$ upoštevanjem sredin razredov pokrovnosti $(5=87,5 \%, 4=$ $62,5 \%, 3=37,5 \%, 2=17,5 \%, 1=5 \%,+=$
0,5\%). Iz njih smo nato izračunali skupno ugotovljeno pokrovnost vegetacije oziroma korigirane deleže. Na lokacijah v kategoriji gozdov smo za vrste, ki so se pojavljale v več plasteh, upoštevali deleže ločeno po teh plasteh. ShannonWiennerjev indeks pestrosti za posamezen popis smo izračunali kot vsoto produktov korigiranih deležev $\left(\mathrm{p}_{\mathrm{i}}\right)$ in logaritmov korigiranih deležev vseh vrst v danem popisu:

$\mathrm{H}=-\mathrm{SUM}\left[\left(\mathrm{p}_{i}\right) \times \ln \left(\mathrm{p}_{i}\right)\right]$

Razlike v številu vrst in vrednosti ShannonWiennerjevega indeksa med lokacijami in kategorijami zelenih površin smo ugotavljali $\mathrm{z}$ analizo variance (ANOVA) z lokacijami popisov kot bloki ter s Tukeyevim post-hoc preizkusom, pri katerem smo upoštevali Bonfferonijevo korekcijo za število primerjav. Različnost/ podobnost celotne vrstne sestave vegetacije po lokacijah in kategorijah zelenih površin smo ugotavljali $\mathrm{s}$ korespondenčno analizo $\mathrm{z}$ odstranjenim trendom; vhodno matriko so predstavljale standardizirane vrednosti pokrovnosti vrst v deležih. Opravili smo več korespondenčnih analiz - posebej za spomladanske in posebej za jesenske popise ter $\mathrm{z}$ in brez upoštevanja gozdnih ploskev.

\subsection{Ekosistemske storitve}

$\mathrm{S}$ pomočjo iskalnega portala ISI Web of Knowledge smo opravili pregled literature na temo zaznanih ES $\mathrm{v}$ mestnih zelenih površinah. 
Uporabili smo naslednje iskalne kriterije (v angleških ustreznicah): ekosistemske storitve parki, ekosistemske storitve - gozd (mestni), ekosistemske storitve - obcestna vegetacija, ekosistemske storitve - degradirana območja, ekosistemske storitve - vrtički, ekosistemske storitve - njive, ekosistemske storitve - zasebni vrtovi, ekosistemske storitve - igrišča/športne površine ter ekosistemske storitve - zelene površine ob blokih. Rezultati iskanja z zaznanimi storitvami znotraj posamezne kategorije zelenih površin v mestu so predstavljeni v Preglednici 2. $\mathrm{Na}$ podlagi podatkov, ki smo jih pridobili iz literature ter terenskih popisov lokacij, smo nato $\mathrm{v}$ izbranih kategorijah zelenih površin $\mathrm{v}$ Ljubljani z ekspertno oceno ocenili, katere od storitev, ki so bile za posamezno kategorijo zelenih površin omenjene $\mathrm{v}$ literaturi, so $\mathrm{v}$ teh kategorijah $\mathrm{v}$ Ljubljani dejansko prisotne. Ekspertne ocene smo opravili trije avtorji prispevka individualno, skupno oceno pa smo sestavili na podlagi večinskega mnenja za vsako kombinacijo kategorije zelene površine in $\mathrm{v}$ literaturi zaznane ES. V analizi smo tudi primerjali, koliko ES za posamezno kategorijo zelene površine smo našli z literaturnim pregledom in koliko ES smo na podlagi te ekspertne ocene pripisali našim proučevanim zelenim površinam v Ljubljani.

Preglednica 2: Seznam ekosisiemskih storitev znotraj posameznik kategorij mestnih zelenih površin iz pregleda literature (znak plus predstavlja zaznano ES v literaturi, navedeni na dnu preglednice)

Table 2: List of assessed ecosystem services in different urban green areas, based on literature review (symbol + represents an assessed ecosystem service appearing in the literature, provided at the bottom of the table)

\begin{tabular}{|c|c|c|c|c|c|c|c|c|c|}
\hline $\begin{array}{l}\text { Ekosistemske storitve / } \\
\text { kategorije zelenih površin v mestu }\end{array}$ & $\underset{\frac{a}{a}}{\frac{a}{2}}$ & 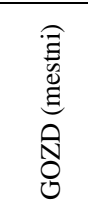 & 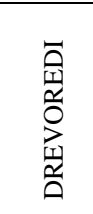 & 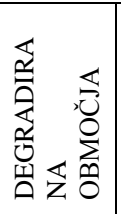 & 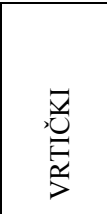 & $\sum_{z}^{M}$ & 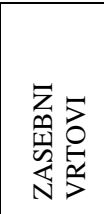 & 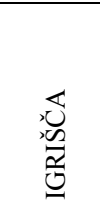 & 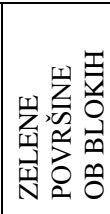 \\
\hline Regulacija vode & + & + & + & + & + & + & + & + & + \\
\hline Življenjski prostor rastlin, živali & + & + & + & & + & & + & & \\
\hline Genetski vir & + & & + & & & & + & + & \\
\hline Skladiščenje ogljika & + & & + & & + & & + & + & \\
\hline Fiksacija $\mathrm{CO}_{2}$ & & + & & & & + & & & \\
\hline Biološki nadzor škodljivcev & + & + & & + & + & + & & & \\
\hline Kakovost zraka & + & + & + & + & + & + & + & & + \\
\hline Vpliv na klimo mesta & + & + & + & & + & + & + & & + \\
\hline Zmanjšanje onesnaženosti z hrupom & + & & + & + & & & & & \\
\hline Regulacija T & + & + & + & + & + & & + & & \\
\hline Proizvajanje $\mathrm{O}_{2}$ & & + & & & & + & & & \\
\hline Ustvarjanje sence & & & + & & & & & & + \\
\hline Opraševanje & + & + & & & + & + & & & \\
\hline Varnost pred erozijo & & + & & & & & & & \\
\hline Ohranjanje narave/biodiverzitete & & + & & + & + & + & + & & \\
\hline Produkcija biomase/Recikliranje odpadkov & & & & + & & & & & \\
\hline Surovine (hrana, les, drugi materiali) & + & + & & & + & + & + & & \\
\hline Turizem & + & + & & & & + & & + & \\
\hline Estetska vrednost & + & + & + & & + & + & & & + \\
\hline Vpliv na fizično dobro počutje & + & + & + & + & + & & + & + & + \\
\hline Psihološki pozitivni vplivi & + & + & + & & + & & & + & \\
\hline Rekreacija & + & & + & & + & + & + & + & + \\
\hline Kulturna dediščina & & & + & & + & + & & & \\
\hline Izobraževalna vrednost & & + & + & & + & + & & & + \\
\hline Omogočanje socialnih interakcij & + & & & + & + & & & & \\
\hline Vir literature & $\underline{\text { Vir 1 }}$ & $\begin{array}{l}\text { Vir 3; } \\
\text { Vir 4; } \\
\text { Vir 5 }\end{array}$ & $\begin{array}{l}\text { Vir 6; } \\
\text { Vir } 7\end{array}$ & $\begin{array}{l}\text { Vir 8; } \\
\text { Vir 9 }\end{array}$ & \begin{tabular}{|l} 
Vir 10; \\
Vir 11; \\
Vir 12 \\
\end{tabular} & \begin{tabular}{|l} 
Vir 13; \\
Vir 14; \\
Vir 15;
\end{tabular} & $\underline{\text { Vir } 16}$ & $\underline{\text { Vir } 17}$ & $\frac{\text { Vir 18; }}{\underline{\text { Vir 19 }}}$ \\
\hline \multicolumn{10}{|c|}{$\begin{array}{l}\text { Opomba: Vir 1 - Kovacs, 2012; Vir } 2 \text { - Buchel in Frantzeskaki, 2015; Vir } 3 \text { - Gorriz-Mifsud in sod., 2016; Vir } 4 \text { - Mislimshoeva in sod., } \\
\text { 2016; Vir 5 - Platon in sod., 2015; Vir 6 - Weber in sod., 2014; Vir } 7 \text { - Saumel in sod., 2016; Vir } 8 \text { - Bardos in sod., 2016; Vir } 9 \text { - Haase } \\
\text { in sod., 2014; Vir 10 - Barthel in sod., 2010; Vir } 11 \text { - Camps-Calvet in sod., 2016; Vir 12 - Middle in sod., 2014; Vir 13 - Ma in sod., } \\
\text { 2015; Vir 14 - Soy-Massoni in sod., 2016; Vir 15 - Firbank in sod., 2013; Vir 16 - Cameron in sod., 2012; Vir 17 - Dai in sod., 2016; Vir } \\
\text { 18 - Krellenberg in sod., 2014; Vir 19 - Norouzian-Maleki in sod., 2015 }\end{array}$} \\
\hline
\end{tabular}




\section{REZULTATI IN DISKUSIJA}

\subsection{Rastlinska pestrost}

Skupno smo popisali 288 različnih rastlinskih vrst. Po vrstni sestavi sta najbolj izstopali kategoriji gozdov in parkov, kjer smo popisali največjo in najbolj raznoliko vrstno sestavo vegetacije. Na gozdni lokaciji Tomačevski prod je bilo tako $\mathrm{v}$ jesenskem kot $\mathrm{v}$ spomladanskem času popisanih največ vrst. V jesenskem času je bilo najmanj vrst popisanih na ploskvi njive na Polju, v spomladanskem času na ploskvi igrišča Kodeljevo. $\mathrm{Na}$ lokaciji parka Tivoli je bila največja razlika $\mathrm{v}$ popisu rastlinskih vrst znotraj in izven ploskve, enako število vrst znotraj in izven ploskve smo popisali na gozdni ploskvi na Golovcu (Slika 1).

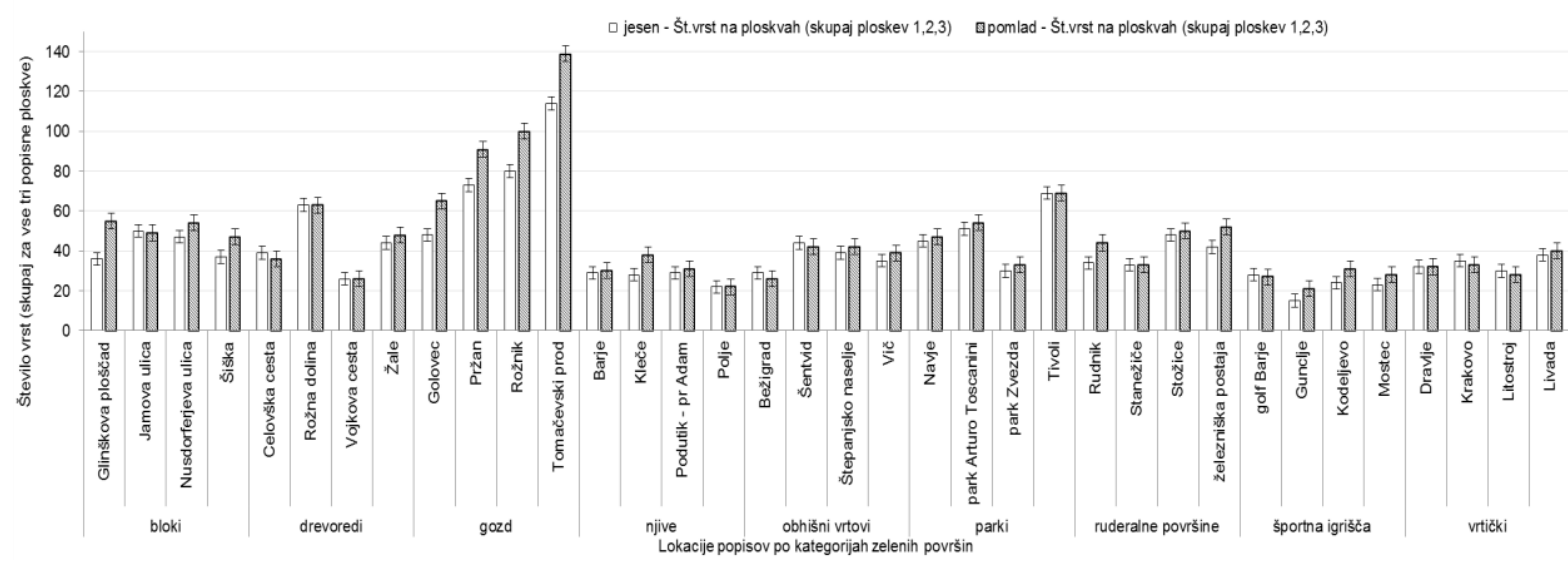

Slika 1: Število vrst na popisnih ploskvah in v neposredni okolici teh ploskev po posameznih popisnih lokacijah, za jesenske in spomladanske popise $\mathrm{v}$ Mestni občini Ljubljana.

Figure 1: Number of species on the plots and around plots for individual locations for the autumn and spring relevés in the Municipality of Ljubljana.

Največ rastlinskih vrst je bilo popisanih $\mathrm{v}$ kategoriji gozdov, sledi kategorija njive, površine ob blokih in drevoredi ter ruderalne površine. Kategoriji z najmanj popisanimi vrstami sta bili igrišča in obhišni vrtovi. Izračunana povprečja števila vrst znotraj posameznih kategorij zelenih površin prikazujejo naslednje rezultate. Največ vrst smo popisali v kategoriji gozdov (68 vrst), sledita ji kategoriji ruderalnih površin (28 vrst) in bloki (26 vrst). Sledijo kategorije drevoredi in njive (obe 25 vrst) ter parki (24 vrst) in vrtički (22 vrst). Najmanj vrst smo v povprečju popisali v kategoriji športnih igrišč (14 vrst). Najmanjša variabilnost med lokacijami popisov je bila opažena med lokacijami vrtičkov, največja med lokacijami v kategoriji obhišnih vrtov in gozdov. ShannonWiennerjev indeks je bil največji $v$ kategoriji gozdov, sledijo ji vrtički, parki in bloki. Najmanjši je bil v kategoriji njiv. Največja razlika med jesenskimi in spomladanskimi vrednostmi indeksa je bila izračunana $\mathrm{v}$ kategoriji igrišč $(0,30)$, najmanjša v kategoriji vrtičkov $(0,07)$.
Primerjava celotne ugotovljene rastlinske pestrosti ter povprečij Shannon-Wiennerjevega indeksa med posameznimi kategorijami zelenih površin $\mathrm{v}$ Ljubljani kaže, da se statistično značilno od ostalih kategorij po številu rastlinskih vrst razlikuje le kategorija gozdov (Slika 2). Med kategorijami vrtički, obhišni vrtovi, njive, ruderalna območja, drevoredi in zelenice ob blokih ni statistično značilnih razlik v številu rastlinskih vrst. Rezultati rastlinske pestrosti v kategoriji igrišč in parkov se prekrivajo s kategorijami vrtički, obhišni vrtovi, njive, drevoredi, zelenice ob blokih in ruderalna območja. V vrednostih Shannon-Wiennerjevega indeksa je statistično značilna razlika opazna med kategorijo gozdov in vsemi ostalimi kategorijami. Med drugimi kategorijami proučevanih zelenih površin ni statistično značilnih razlik. Statistično značilnih razlik nismo ugotovili niti med kategorijami zelene površine ob blokih, obhišni vrtovi, vrtički, parki, drevoredi in ruderalna območja. 


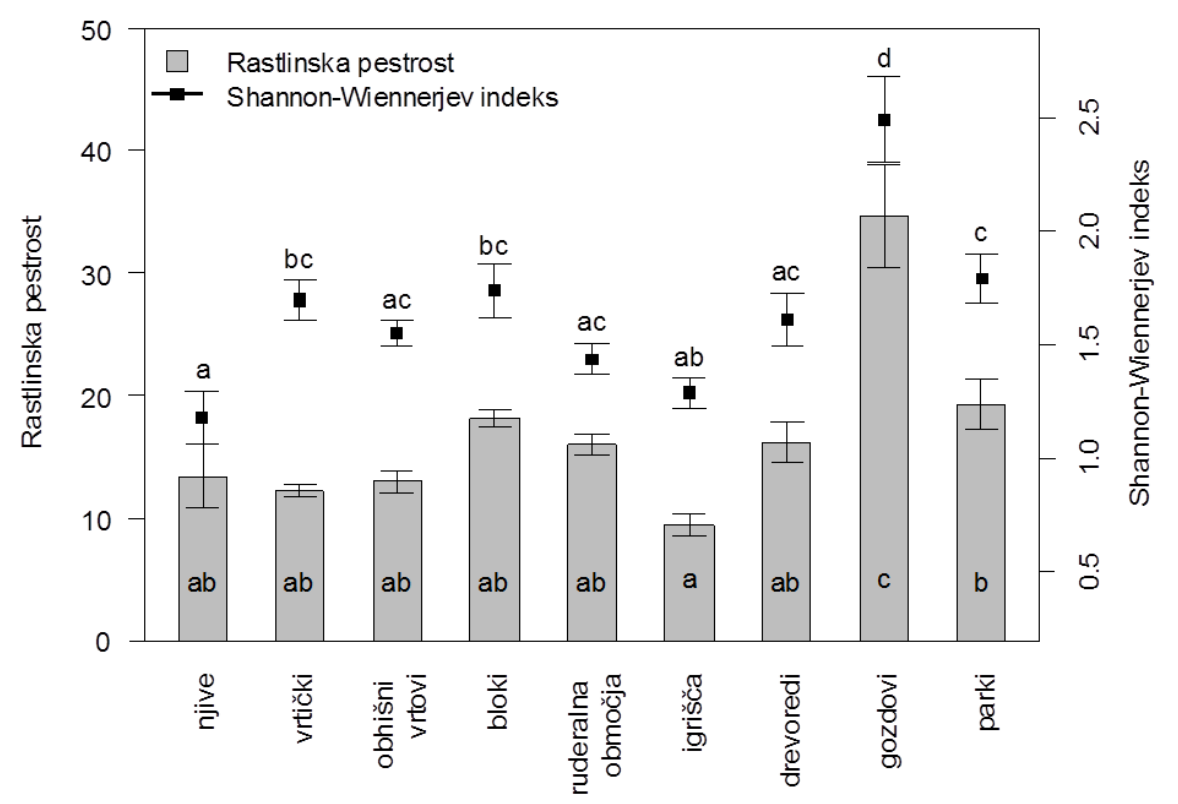

Slika 2: Podatki rastlinske pestrosti in povprečij Shannon- Wiennerjevega indeksa po posameznih kategorijah zelenih površin v Mestni občini Ljubljana

Figure 2: Number of species and average values of Shannon - Wienner index by categories of green infrastructure in the Municipality of Ljubljana

Korespondenčno analizo podobnosti popisov $\mathrm{v}$ celotni sestavi rastlinskih združb smo opravili za jesenski in spomladanski del popisov posebej. Sestava ter različnost sestave (variabilnosti med lokacijami in ploskvami) kažeta na to, da so gozdne ploskve precej drugačne od preostalih tako $\mathrm{v}$ jesenskem kot $\mathrm{v}$ spomladanskem obdobju popisa (Slika 3 - jesenski popisi). Zaradi tega smo korespondenčno analizo ponovili z upoštevanjem samo negozdnih lokacij (Slika $3 \mathrm{e}$ in 3f). Zaradi večjega deleža enoletnih vrst so nekoliko ločene njivske površine in delno vrtički. Podobnost je posebej opazna na površinah s traviščno vegetacijo - zelene površine ob blokih, drevoredi, igrišča, vrtovi ob hišah in parki. 

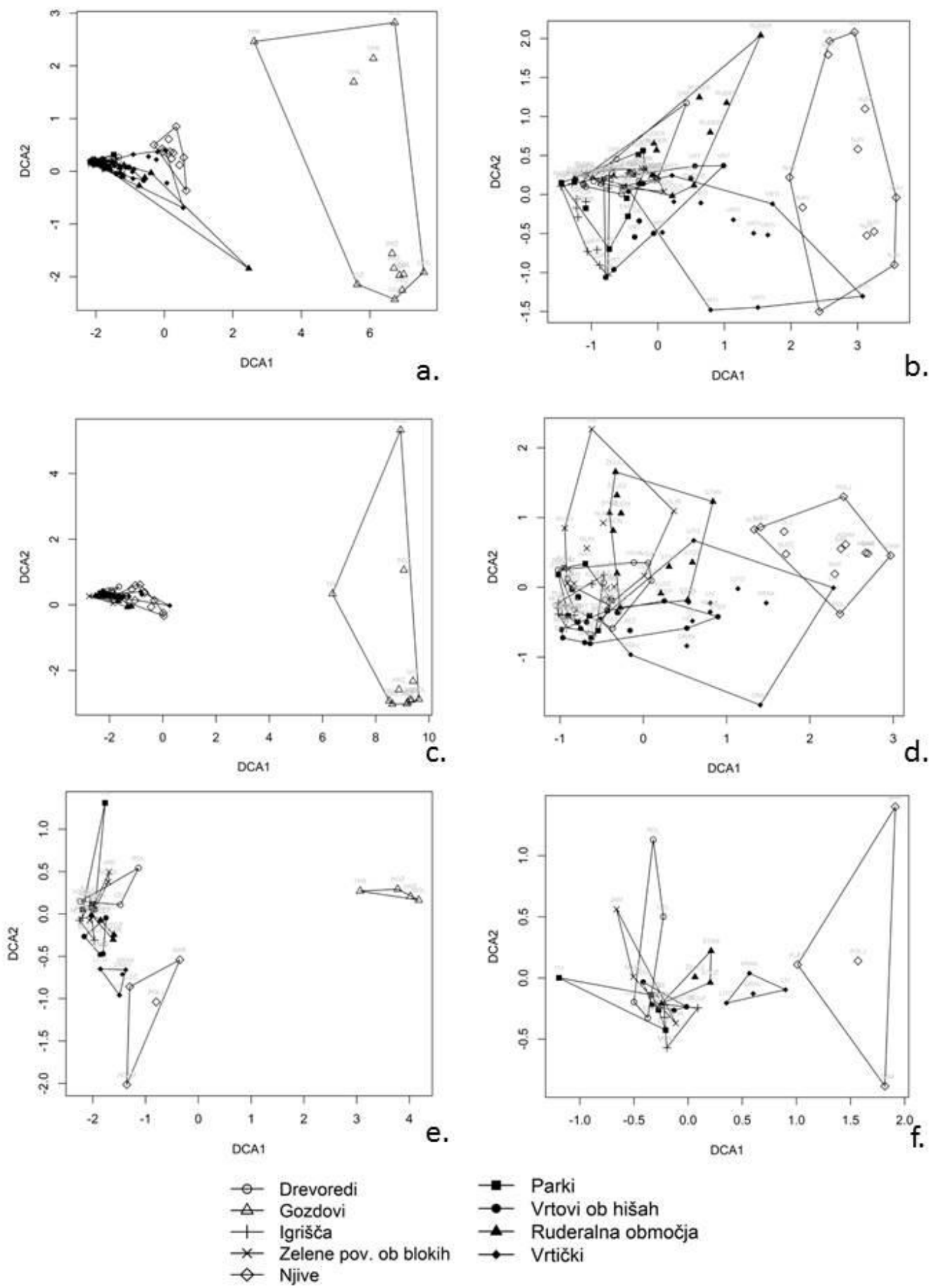

Slika 3: Rezultati (ordinacijski diagrami za prve dve osi) korespondenčne analize za sestavo rastlinskih združb na zelenih površinah v Ljubljani; a) ordinacija jesenskih popisov upoštevajoč pokrovnost vrst; b) enako kot a) le brez gozdnih ploskev; c) ordinacija spomladanskih popisov zelenih površin v Ljubljani na prvih dveh oseh korespondenčne analize, upoštevajoč pokrovnost vrst; d) enako kot c) le brez gozdnih ploskev; e) ordinacija popisanih lokacij, upoštevajoč le prisotnost vrst (združeni jesenski in spomladanski popisi treh ploskev na lokacijo); f) enako kot e) le brez gozdnih ploskev.

Figure 3: Correspondence analysis results (ordination diagrams for the first two axes): a) autumn relevés of land cover in green spaces in Ljubljana; b) same as a. except forest relevés; c) spring relevés of land cover in green spaces of Ljubljana; d) same as c. except forest relevés; e) autumn and spring relevés (three plots per location), showing only the results of the presence of the species; f) same as e. except forest relevés. 


\subsection{Ekosistemske storitve}

Največ storitev (izračunano je bilo povprečje iz vseh lokacij znotraj posamezne kategorije) je bilo na podlagi ekspertne ocene na terenu zaznano $\mathrm{v}$ kategoriji gozd ter vrtički, sledita kategoriji parki in drevoredi. Povprečno najmanj storitev smo na terenu zaznali $\mathrm{v}$ kategoriji igrišč in ruderalnih območij. Med popisnimi lokacijami sta pri terenskih popisih izstopali gozdni lokaciji Rožnik in Golovec $z$ največjim številom zaznanih ES, najmanj pa smo jih ugotovili na lokaciji gramoznice Stanežiče v kategoriji ruderalnih območij. Na proučevanih kategorijah zelenih površin smo največkrat določili naslednje ES: vpliv na kakovost zraka $\mathrm{v}$ mestu, vpliv na fizično dobro počutje ter rekreacija. V najmanj kategorijah sta bili ugotovljeni varstvo pred erozijo ter produkcija biomase. Največja razlika v številu ES najdenimi v literaturi in številu ES za naše lokacije po ekspertni oceni je prisotna $\mathrm{v}$ kategoriji parki (Slika 4). Sledita ji kategoriji njive in ruderalna območja, kjer razlika znaša 3 storitve.

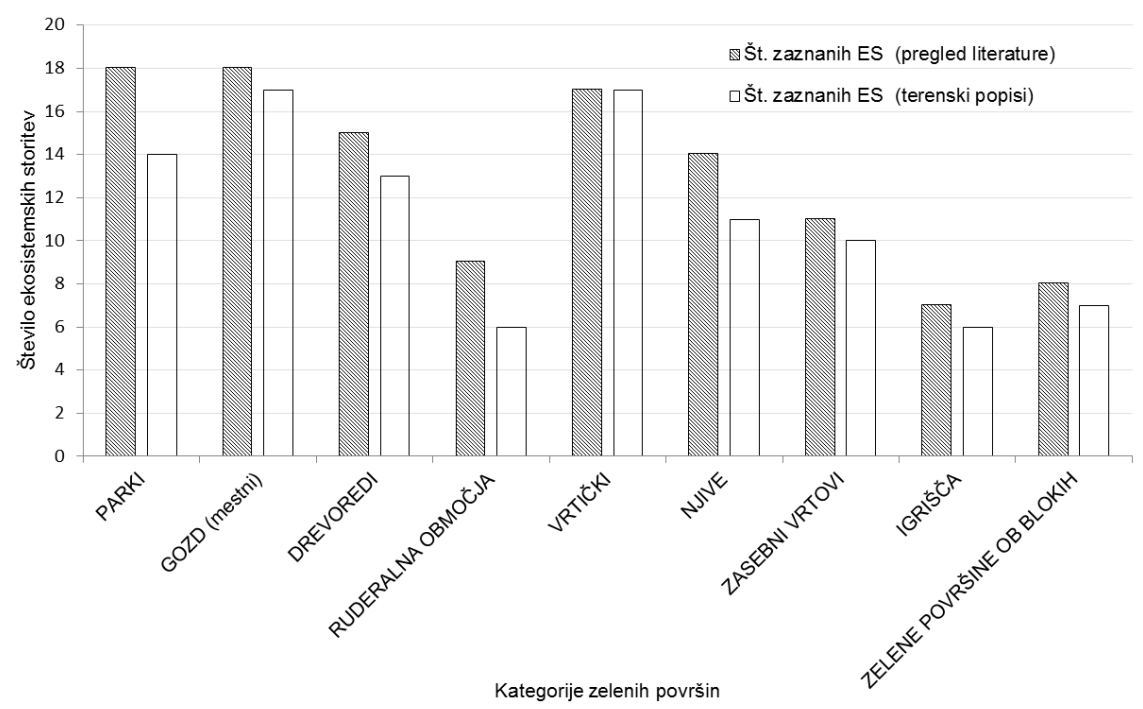

Slika 4: Povprečno število ES na podlagi pregleda literature ter število storitev po ekspertni oceni v izbranih kategorijah zelenih površin v Mestni občini Ljubljana

Figure 4: Average number of ecosystem services reported in the literature and the number of assessed services according to the expert evaluation for the selected categories of green infrastructure in the Municipality of Ljubljana

\subsection{Povezanost rastlinske pestrosti in ekosistemskih storitev}

Glede na podatke, prikazane na Sliki 5, lahko povzamemo, da je bilo največ vrst popisanih $\mathrm{v}$ kategoriji gozdov, ta kategorija je imela tudi največ ES. V nadaljnji analizi smo izračunali Pearsonov koeficient korelacije (statistično značilen pri $p<0,01)$ med spremenljivkama število vrst na ploskvi in povprečnim število ES $\mathrm{v}$ posamezni kategoriji ter vrednostjo Shannon-Wiennerjev indeks in povprečnim številom ES. Koeficient je bil $\mathrm{v}$ prvem primeru 0,48 , pri primerjavi pestrosti Shannon-Wiennerjevega indeksa pa 0,59 . Iz tega lahko sklepamo, da je med spremenljivkama majhna pozitivna povezanost oz. pri večjem številu vrst pričakujemo tudi več ES. 


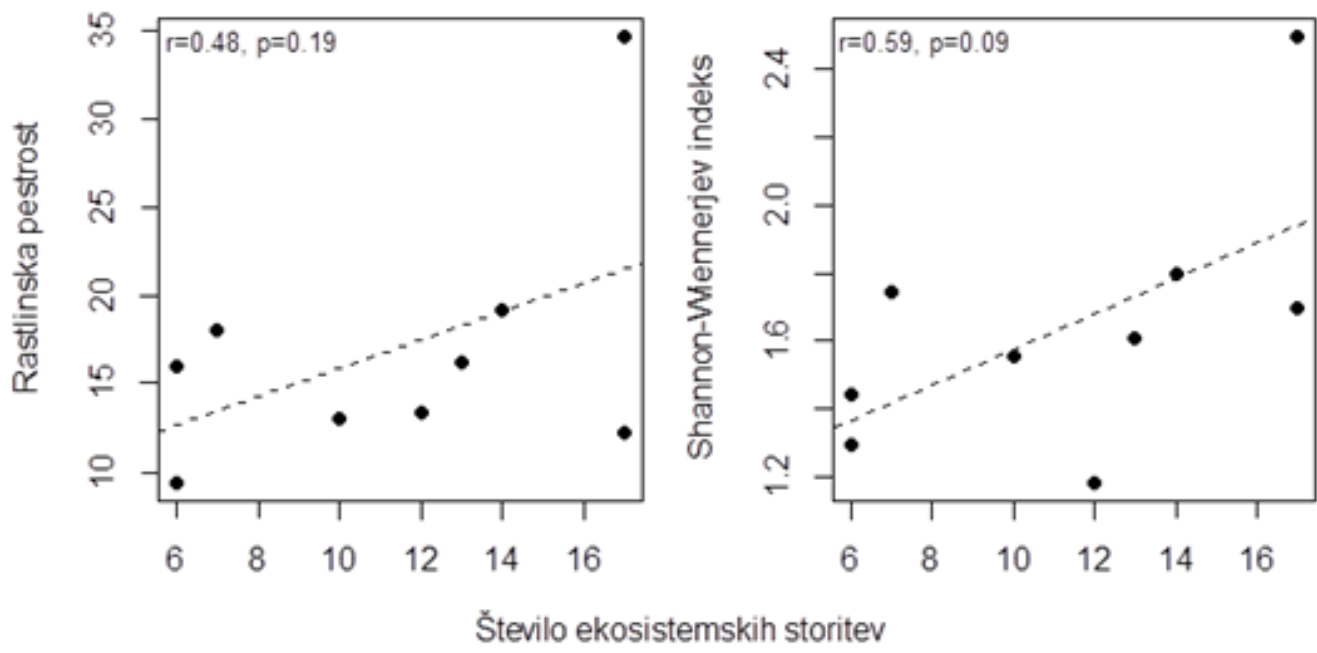

Slika 5: Primerjava skupnega števila popisanih rastlinskih vrst ter povprečnega števila ES na posamezni lokaciji zelenih površin $\vee$ Mestni občini Ljubljana (levo); primerjava Shannon-Wiennerjevega indeksa pestrosti ter povprečnega števila ES v posamezni kategoriji zelenih površin v Mestni občini Ljubljana (desno)

Figure 5: Number of inventoried plant species and average number of ES at each location of green infrastructure categories in the Municipality of Ljubljana (left); Shannon-Wienner inedx compared with the average number of ES of each category of green infrastructure categories in the Municipality of Ljubljana (right)

\subsection{Diskusija}

Mesta so s strani človeka tako izrazito vplivana okolja $\mathrm{z}$ uničeno ali znatno spremenjeno vegetacijo, da je $\mathrm{v}$ njih nabor in pomen ES prvotnih naravnih ekosistemov v največji možni meri predrugačen. Kljub temu morajo mesta tudi kot takšni intenzivno spremenjeni ekosistemi mestnim prebivalcem nuditi pomembne storitve, kot so vzdrževanje življenjskih razmer (Odum, 1989), varnost (Costanza in sod., 2006), dobro počutje (TEEB, 2011), zdravje (Maas in sod., 2006) ter socialne interakcije (EEA, 2011). Kot smo omenili že v uvodu, se nakazuje, da je nabor $\mathrm{ES}$ in njihova kvaliteta $\mathrm{v}$ povezavi tudi $\mathrm{z}$ biotsko pestrostjo mestnih območij, posebej zelenih površin. To povezavo smo na različnih kategorijah zelenih površin preverili tudi za mesto Ljubljana.

Med proučevanimi zelenimi površinami je pričakovano izstopala kategorija gozdov, saj gre za ekosisteme najbližje prvotnim oz. naravnim, katerih vrstna sestava, različnost in strukturiranost življenjskih oblik se zelo razlikuje od drugih ZP. Večina vrst, ki jih najdemo $\mathrm{v}$ gozdovih, težko uspeva $\mathrm{v}$ kaki drugi kategoriji zelenih površin $\mathrm{v}$ Ljubljani. Druge kategorije namreč sodijo v skupino t. i. motenih habitatov, kjer se po bolj ali manj celotni površini izvaja teptanje s hojo ljudi ali vozili, košnja idr., kar onemogoča ali otežuje rast lesnatih vrst, razen če so te izrecno vzdrževane. Prav lesnate vrste oz. gozdni ekosistemi naj bi najbolj zmanjševali odtok površinske vode (Villarreal in Bengtsson, 2005), je pa bila ta ES v naši raziskavi ugotovljena tudi za večino negozdnih kategorij. Povsod, kjer tla namreč niso nepropustna (asfaltirana, betonirana) in so porasla $\mathrm{Z}$ vegetacijo, je ta storitev ugotovljena.

Le nekoliko manj ES kot za gozdove smo jih ugotovili za parke. Ljubljana med evropskimi mesti ni izrazito bogata $\mathrm{z}$ deležem parkovnih površin (Braquinho in sod., 2015), kar je dokaj značilno za nekoliko manjša mesta $\mathrm{z}$ dobro dostopnostjo zelenih površin izven mesta. Poleg tega se skoraj $\mathrm{v}$ center Ljubljane zajedata dve gozdni območji (Rožnik in Golovec), ki se v evidencah ne vodita kot parkovni površini, imata pa podobni funkciji. Rezultati kažejo, da se največji park v Ljubljani (Tivoli) razlikuje od ostalih izbranih parkovnih površin tako po številu ES kot tudi po številu rastlinskih vrst. Park Tivoli je del krajinskega parka, $v$ njem velja posebna ureditev, prav tako je po svoji površini tudi največji in po svojih funkcijah za mestno prebivalstvo bolj raznolik.. Pomembna vloga parkovnih površin ugotovljenih na primeru Ljubljane ter zelenih površin ob blokih, ki jih lahko pojmujemo kot pomanjšane parke, ni presenetljiva. Hardin in Jensen (2007) sta npr. 
ugotovila, da te površine značilno zmanjšujejo temperaturo $\mathrm{v}$ mestu, saj vegetacija teh večjih površin s pomočjo evapotranspiracije zmanjšuje temperaturo. Prav tako drevesa v mestu, ki so del tako mestnih gozdov kot parkovnih površin in drevoredov, vplivajo na temperaturo $\mathrm{v}$ mestu $\mathrm{z}$ ustvarjanjem sence (Bolund in Hunhammar, 1999).

Kategorijam vrtičkov, skupnostnih vrtov in vrtov ob hišah smo ugotovili veliko storitev, povezanih $\mathrm{s}$ socialno funkcijo. Med glavne socialne koristi, ki jih take površine omogočajo uvrščamo: izobraževanje o naravi in pridelavi hrane, socialna kohezija, ki združuje ljudi iz različnih okolij, ki imajo skupni interes za vrtnarjenje in zdravstvene koristi z zmerno telesno aktivnostjo, predvsem za starejše ljudi (Speak in sod., 2015). To lahko potrdimo tudi $\mathrm{z}$ našimi rezultati, saj so bile te storitve ugotovljene $\mathrm{v}$ vseh lokacijah popisov $\mathrm{v}$ kategoriji vrtičkov.

Mestno kmetijstvo je $\mathrm{v}$ Ljubljani in tudi drugih mestih različnih oblik (vrtički, skupnostni vrtovi, zasebni vrtovi, zelene strehe), vendar imajo vse te oblike skupen namen. McGranahan in sod. (2005) navajajo, da mnogim mestnim prebivalcem te površine predstavljajo pomemben vir hrane ter vir dodatne oskrbe in zaslužka. To velja tudi $\mathrm{v}$ Ljubljani, saj kategoriji zasebnih vrtov in mestnih vrtičkov glede na povpraševanje mestnih prebivalcev pridobivata na pomenu.

Pri vseh zelenih površinah v mestu smo ugotovili njihov pomen za kakovost zraka ter vpliv na mestno mikroklimo. Glavni onesnaževalci v mestu, kot so industrija, transport in ogrevanje pripomorejo $\mathrm{k}$ slabšanju kakovosti življenja $\mathrm{v}$ mestu. Nowak (1996) ugotavlja, da različne oblike vegetacije $\mathrm{v}$ mestu vplivajo na kakovost zraka $\mathrm{z}$ odstranjevanjem onesnažil, predvsem ozona, dušikovih oksidov in žveplovega dioksida. To poteka $\mathrm{z}$ absorpcijo in adsorpcijo na liste in druge dele mestnih dreves in ostale vegetacije. Rezultati kažejo, da se je to kot pomembno izkazalo predvsem v kategoriji gozd, parki, zelene površine ob blokih, vrtički in drevoredi, kjer je več drevesne vegetacije, v ostalih kategorijah te ES niso bile ugotovljene kot pomembne.

V kategoriji ruderalnih površin je število pripisanih ES zelo majhno, čeprav smo na teh lokacijah popisali razmeroma veliko rastlinskih vrst, vendar pa je funkcionalna pestrost popisane vegetacije manjša (pretežno gre za steblikaste zelnate vrste zgodnjih in srednjih faz sukcesije). Manjkajo večja drevesa in grmi in s tem tudi številne storitve, ki jih srečamo $v$ tistih kategorijah, kjer so ti rastlinski tipi dominantni. Pozitivni prispevek teh lokacij je lepši videz mesta, saj namesto zapuščenih, sivih površin ta območja prerašča zelena in občasno tudi cvetoča (sub)spontana vegetacija. Na tem mestu ne moremo mimo problematike invazivnih vrst, ki se pojavljajo na teh površinah in se hitro širijo. Čeprav te vrste omogočajo ozelenitev zapuščenih površin $\mathrm{v}$ mestu in tako $\mathrm{v}$ očeh prebivalcev prispevajo k ozelenitvi mesta, so lahko pomemben vir propagulov teh invazivnih vrst, ki tako lahko vdirajo na druge površine, kjer niso zaželene in tam povzročajo gospodarsko škodo, težave pri zdravju ljudi ali pa izrinjajo avtohtono vegetacijo.

$\mathrm{V}$ primerjavi povezanosti med številom ES in velikostjo biotske pestrosti smo ugotovili pozitivno zvezo med številom vrst $\mathrm{v}$ združbi in številom ugotovljenih ES - več vrst smo ugotovili tam, kjer je tudi več ES. Pri tem je treba opozoriti, da s to raziskavo ne moremo dokazati vzročno posledične zveze, torej da večja biotska pestrost omogoča večje število ES, saj sta tako število vrst kot število ES lahko hkrati posledici drugih dejavnikov- npr. režima motenj oz. režima upravljanja $\mathrm{Z}$ ekosistemom. Nasploh je potrebno opozoriti, da je proučevanje ekologije mest izredno težavno, saj se $\mathrm{v}$ mestih izrazito prepletajo in medsebojno učinkujejo naravni, ekonomski, kulturnozgodovinski in sociološki dejavniki. Raba mestnih zelenih površin in $\mathrm{s}$ tem povezane ES posamezne površine se lahko za isto kategorijo izrazito razlikujejo in niso $\mathrm{v}$ celoti pojasnljive. Določene vzorce in uporabnost izsledkov pri načrtovanju mestnih zelenih površin bo zato možno pridobiti le ob sintezi večjega števila podobnih analiz. 


\section{SKLEPI}

Zelene površine zagotavljajo široko paleto ES v urbanih območjih. Storitve, povezane $\mathrm{z}$ pridelavo hrane, biotsko raznovrstnostjo, opraševanjem in rekreacijo so najbolj značilne in prepoznane $\mathrm{v}$ teh kategorijah. Te storitve imajo velik pomen $\mathrm{v}$ mestih, predvsem zaradi velike gostote prebivalcev, prometa in pozidanih površin v mestu. V prvi vrsti velja poudariti, da tudi $\mathrm{v}$ Ljubljani najvidnejšo vlogo igrajo zgoraj omenjene ES. To se kaže predvsem v vplivu, ki ga imajo zelene površine in pripadajoče ES na kakovost zraka $\mathrm{v}$ mestu, uravnavanje onesnaženosti okolja, omogočanje rekreacije in socialnih interakcij ter človekovo dobro počutje.
Zato se je $\mathrm{v}$ prihodnje potrebno osredotočiti na načine načrtovanja in upravljanja mest, ki bodo ohranjala ključne komponente ekosistemov, v prvi vrsti naravno biotsko raznovrstnost, ki zagotavlja največ ES. Izguba ES lahko $\mathrm{v}$ mestih privede do mnogih negativnih vplivov. Predvsem bodo to vplivi na gospodarstvo, socialo, zdravje ljudi ter kulturo mesta $\mathrm{S}$ pravim načinom upravljanja se izboljša dolgoročno zdravje ekosistemov in posledično zagotavljanja obstoj ekosistemskih storitev, ki so ključnega pomena za preživetje vseh živih bitij v mestu.

\section{ZAHVALA}

Raziskavo je finančno delno podprl projekt GREEN SURGE, EU collaborative project, FP7ENV.2013.6.2-5-603567.

\section{VIRI}

Balvanera, P., Pfisterer, A. B., Buchmann, N., He, J. S., Nakashizuka, T., Raffaelli, D., Schmid, B. (2006). Quantifying the evidence for biodiversity effects on ecosystem functioning and services. Ecology Letters, 9 , (10), 1146-1156. doi:10.1111/j.14610248.2006.00963.x

Baycan-Levent, T., Vreeker, R., Nijkamp, P. (2009). A multi-criteria evaluation of green spaces in European cities. European Urban and Regional Studies, 16 (2), 193-213. doi:10.1177/0969776408101683

Bardos, R.P., Jones, S., Stephenson, I., Menger, P., Beumer, V., Neonato, F., Maring, L., Ferber, L., Track, T., Wendler, K. (2016). Optimising value from the soft re-use of brownfield sites. Science of The Total Environment, 563-564, 769-782. doi:10.1016/j.scitotenv.2015.12.002

Barthel, S., Folke, C., Colding J. (2010). Social-ecological memory in urban gardens- Retaining the capacity for management of ecosystem services. Global Environmental Change, 20(2), 255-265. doi:10.1016/j.gloenvcha.2010.01.001

Bolund, P., \& Hunhammar, S. (1999). Ecosystem services in urban areas. Ecological Economics, 29 (2), 293301. doi:10.1016/S0921-8009(99)00013-0

Botzat, A., Fisher, K.L., Kowarik, I. (2016). Unexploited opportunities in understanding liveable and biodiverse cities. A review on urban biodiversity perception and valuation. Global Environmental Change, 39, 220233. doi:10.1016/j.gloenvcha.2016.04.008

Borysiak, J., Mazurek, M., Zwolinski, Z. (2014). Land cover ecosystem services changes in agricultural landscapes of the Debnica catchment (west Pomerania, Poland). Ekon. Srodowisko, 4 (51), 205220.

Braquinho C., Cvejić R., Eler K., Gonzales P., Haase D., Hansen R., Kabisch N., Lorance Rall E., Niemela J., Pauleit S., Pintar M., Lafortezza R., Santos A., Strohbach M., Vierikko K., Železnikar Š. 2015. A typology of urban green spaces, ecosystem provisioning services and demands. Project report EU FP7 (ENV.2013.6.2-5-603567) GREEN SURGE project (2013-2017). Retrieved from http://greensurge.eu/workingpackages/wp3/files/D3.1_Typology_of_urban_green_ spaces_1_.pdf/D3.1_Typology_of_urban_green_space s_v2_.pdf

Buchel, S., \& Frantzeskaki, N. (2015). Citizens`voice: A case study about perceived ecosystem services by urban park users in Rotterdam, the Netherlands. Ecosystem Services, 12, 169-177. doi:10.1016/j.ecoser.2014.11.014 
Cardinale, B.J. (2011). Biodiversity improves water quality through niche partitioning. Nature, 472, 86-91. doi:10.1038/nature09904

Cameron, W.F.R., Blanuša, T., Taylor, E.J., Salisbury, A., Halstead J.A., Henricot, B., Thompson, K. (2012). The domestic garden - Its contribution to urban green infrastructure. Urban Foresty and Urban Greening, 11(2): 129-137. doi:10.1016/j.ufug.2012.01.002

Camps-Calvet, M., Langemeyer, J., Calvet-Mir, L., Gómez-Baggethun, E. (2016). Ecosystem services provided by urban gardens in Barcelona, Spain: Insights for policy and planning. Environmental Science and Policy, 62, 14-23. doi:10.1016/j.envsci.2016.01.007

Cilliers, S., Cilliers, J., Lubbe, R., Siebert, S. (2013). Ecosystem services of urban green spaces in African countries-prespectives and challenges. Urban Ecosystem, 16, 681-702. doi:10.1007/s11252-0120254-3

Costanza, R., d`Arge, R., De Groot, R., Farber, S., Grasso, M., Hannon, B., in sod. (1997). The value of the world's ecosystem services and natural capital. Nature, 387, 253-260. doi:10.1038/387253a0

Costanza, R., Mitsch, W.J., Day, Jr., J.W. (2006). A new vision for New Orleans and the Mississippi delta: applying ecological economics and ecological engineering. Frontiers in Ecology and the Environment 4, 465-472, doi. 10.1890/15409295(2006)4[465:ANVFNO]2.0.CO;2

Dai, Z., Puyang, X., Han, L. 82016). Using assessment of net ecosystem services to promote sustainability of golf course in China. Ecological Indicators, 63, 165171. Doi:10.1016/j.ecolind.2015.11.056

De Bello, F., Lavorel, F., Diiaz, S., Harrington, R., Bardgett, R., in sod. (2010). Functional traits underline the delivery of ecosystem services across different trophic levels. Biodiversity Conservation, 143, 2873-2893. doi:10.1007/s10531-010-9850-9

Díaz, S., Tilman, D., Fargione, J., Chapin, F. S. III, Dirzo, R., Katzberber, T. in sod. (2005). Biodiversity regulation of ecosystem services. V: Trends and Conditions. Washington, DC, Island Press: 279-329.

Dierschke, H. (1994). Pflanzensoziologie, Grundlagen und Methoden Systematisch. Göttingen, Geobotanisches Institut und Universität.

EEA: European Environmental Agency. (2011). Green infrastructure and territorial cohesion. The concept of green infrastructure and its integration into policies using monitoring systems. EEA Technical report, 18. European Environment Agency. Retrieved from http://www.eea.europa.eu/publications/greeninfrastructure-and-territorial-cohesion
European Commission, 1996. European Sustainable Cities. Report by the Expert Group on Urban Environment, Brussels, CR-97-96-055-EN-C.

Egoh, B., Reyers, B., Rouget, M., Bode, M., Richardson, D.M. (2009). Spatial congruence between biodiversity and ecosystem services in South Africa. Biological Conservation, $\quad$ 553-562. doi:10.1016/j.biocon.2008.11.009

Firbank, L., Bradbury, B.R., McCracken, I.D., Stoate, C. (2013). Delivering multiple ecosystem services from Enclosed Farmland in the UK. Agriculture, Ecosystem and Environmnet, 166, 65-75. doi:10.1016/j.agee.2011.11.014

Gómez-Baggethun, E., \& Barton, D. N. (2013). Classifying and valuating ecosystem services for urban planning. Ecological Economics, 86, 235-245. doi:10.1016/j.ecolecon.2012.08.019

Górriz-Mifsud, E., Varela, E., Piqué, M., Prokofieva, I. (2016). Demand and supply of ecosystem services in Mediterranean forest: Computing payment boundaries. Ecosystem Services, 17, 53-63. doi:10.1016/j.ecoser.2015.11.006

GS: Green Surge official website. (2016). Retrieved from http://greensurge.eu/

Hardin, P.J., Jensen, R.R., (2007). The effect of urban leaf area on summertime urban surface kinetic temperatures: a Terre Haute case study. Urban Forestry \& Urban Greening 6, 63-72. doi:10.1016/j.ufug.2007.01.005

Harrison, P.A., Berry, P.M., Simpson, G., Haslett, J.R., Blicharska, M., Bucur, M., Dunford, R., in sod. (2014). Linkages between biodiversity attributes and ecosystem services: a systematic review. Ecosystem services, 9, 191-203. doi:10.1016/j.ecoser.2014.05.006

Haase, D., Haase, A., Rink, D. (2014). Conceptualizing the nexus between urban shrinkage and ecosystem services. Landscape and Urban Planning, 132, 159169. doi:10.1016/j.landurbplan.2014.09.003

Isbell, F., Calcagno, V., Hector, A., Connolly, J., Harpole, S.W., Reich, B.P., in sod. (2011). High plant diversity is needed to maintain ecosystem services. Nature, 477 , 199-202. doi:10.1038/nature10282

Jax, K., \& Ulrich, H. (2015). Searching for the place of biodiversity in the ecosystem service discourse. Biological Conservation, 191, 198-205. doi:10.1016/j.biocon.2015.06.032

Kovacs, F.K. (2012). Integrating property value and local recreation models to value ecosystem services from regional parks. Landscape and Urban Planning, 108, 79-90. doi:10.1016/j.landurbplan.2012.08.002

Krellenberg, K., Welz, J., Reyes-Paecke, S. (2014). Urban green areas and their potential for social interaction A case study of a socio-economically mixed 
Vroča točka v mestu: povezava ekosistemskih storitev in biotske pestrosti mestnih zelenih površin

neighbourhood in Santiago de Chile. Habitat International, $\quad 44, \quad 11-21$. doi:10.1016/j.habitatint.2014.04.004

Loreau, M., Naeem, S., Inchausti, P., Bengtsson, J., Grime, J.P., Hector, A., Hooper, D.U., in sod. (2001). Biodiversity and ecosystem functioning: current knowledge and future challenges. Science, 294, 804809. doi:10.1126/science. 1064088

Ma, F., Eneji, A.E., Liu, J. (20156). Assessment of ecosystem services and dis-services of an agroecosystem based on extended emergy framework: A case study of Luancheng county, North China. Ecological Engineering, 82, 241-251. doi:10.1016/j.ecoleng.2015.04.100

Maas, J., Verheij, R.A., de Groenewegen, P.P., Vries, S., Spreeuwenberg, P., (2006). Green space, urbanity, and health: how strong is the relation? Journal of Epidemiology and Community Health, 60, 587-592. doi:10.1136/jech.2005.043125

Mace, G.M., Norris, K., Fitter, A.H. (2012). Biodiversity and ecosystem services: a multilayered relationship. Trends in Ecology and Evolution, 27, 19-25. doi:10.1016/j.tree.2011.08.006

McGranahan, G., Marcotulillo, P., Bai, X., Balk, D., Braga, T., Douglas, I., Elmqvist, T., in sod. (2005). Urban systems. V: Ecosystems and Human Well-Being: Current Status and Trends. Hassan R., Scholes R., Ash N. (eds). Washington DC, Island Press: 795-825

McKinney, M. L. (2006). Urbanisation is a major course of biotic homogenization. Biological Conservation, 127, 247-260. doi:10.1016/j.biocon.2005.09.005

MEA: Millennium Ecosystem assessment. (2005). Ecosystems and human well-being: Synthesis. Island Press. Washington DC. Retrieved from http://www.pnas.org/content/106/5/1305.full.pdf+html

Middle, I., Dzidic, P., Buckley A., Bennett, D., Tye, M., Jones, R. (2014). Integrating community gardens into public parks: An innovative approach for providing ecosystem services in urban areas. Urban Forestry and Urban Greening, 13(4), 638-645. doi:10.1016/j.ufug.2014.09.001

Mislimshoeva, B., Herbst, P., Koellner, T. (2016). Current pathways towards good forest governance for ecosystem services in the former Soviet republic Tajikistan. Forest Policy and Economics, 63, 11-19. doi:10.1016/j.forpol.2015.12.002

Norouzian-Maleki, S., Bell, S., Hosseini, S.B., Faizi, M. (2015). Developing and testing a framework for the assessment of neighbourhood liveability in two contrasting countries: Iran and Estonia. Ecological Indicators, $48, \quad 263-271$. doi:10.1016/j.ecolind.2014.07.033

Nowak, D. J. (1996). Estimating leaf area and leaf biomass of open-grown decidius urban trees. Forest Science, 42, 504-507.

Odum, E.P., (1989). Ecology and Our endangered Life Support System. Sinauer Association, Sunderland.

Platon, V., Frone, S., Constantinescu, A. (2015). New developments in assessing forest ecosystem services in Romania. Procedia Economica and Finance, 22, 45-54. doi:10.1016/S2212-5671(15)00225-7

Sämuel, I., Weber, F., KOwarik, I. (2016). Toward livable and healthy urban streets: Roadside vegetation provides ecosystem services where people live and move. Environmental Science and Policy, 62, 24-33. doi:10.1016/j.envsci.2015.11.012

Schneider, A., Logan, K. E., Kucharik, C. J. (2012). Impacts of urbanization on ecosystem goods and services in the U.S. Corn Belt. Ecosystems, 15, 519541. doi:10.1007/s10021-012-9519-1

Smith, R.M., Gaston, K.J., Warren, P.H., Thompson, K. (2006). Urban domestic gardens (Viii): environmental correlates of invertebrate abundance. Biodiversity conservation, 15, 2515-2545. doi:10.1007/s10531005-2784-y

Soy-Massoni, E., Langemeyer, J., Varga, D., Sàez, M., Pintó, J. (2016). The importance of ecosystem services in coastal agricultural landscapes: Case study from the Costa Brava, Catalonia. Ecosystem Services, 17, 4352. doi:10.1016/j.ecoser.2015.11.004

TEEB: The Economics of Ecosystems and Biodiversity. (2011). Manual for Cities: Ecosystem Services in Urban Management. UNEP and the European Commission. Retrieved from http://www.teebweb.org/wpcontent/uploads/Study\% 20and\%20Reports/Additional\%20Reports/Manual $\% 2$ 0for\%20Cities/TEEB\%20Manual\%20for\%20Cities_E nglish.pdf

Villarreal, E.L., \& Bengtsson, L., (2005). Response of a Sedum green-roof to individual rain events. Ecological Engineering 25, 1-7. doi:10.1016/j.ecoleng.2004.11.008

Weber, F., Kowarik, I., Sämuel, I. (2014). A walk on the wild side: Perceptions of roadside vegetations beyond trees. Urban Forestry and Urban Greening, 13(2), 205-212. doi:10.1016/j.ufug.2013.10.010 